\title{
Meme literacy in Russia: Perceptions of internet memes by a student audience and issues of critical thinking
}

\author{
(10 \\ Svetlana Shomova \\ ORCID: 0000-0003-0959-9278 \\ NATIONAL RESEARCH UNIVERSITY HIGHER SCHOOL OF ECONOMICS, RUSSIA \\ https://doi.org/10.19195/1899-5101.13.2(26).7
}

\begin{abstract}
Internet memes, which constitute a significant portion of social-media content and an important vector of users' communicative exchange, have by now turned from mere entertainment to a news source. However, they are still approached rather uncritically by young audiences. A survey was conducted among Russian students $(N=138)$ at the National Research University Higher School of Economics, and it identified not only the "problem spots" of the Russian memosphere but also a number of skills in decoding information, which are necessary today as part of "Meme Literacy." These skills range from an adequate assessment of the type of message and verification of the news topic to the fact-checking of the verbal and visual content the meme is based on.
\end{abstract}

KEYWORDS: new media, internet memes, memosphere, new literacies, meme literacy, Russia

\section{INTRODUCTION}

Internet memes are among those features of digital culture that, on the one hand, have already been studied extensively by specialists in the humanities bu,t on the other hand, continue to provoke new questions and heated debates. Furthermore, the contemporary understanding of this phenomenon, particularly in its online version, has moved a long way from Richard Dawkins' classic definition. Having first introduced the term, Dawkins (1976) defined it as a unit of transmission of cultural heritage, a certain cultural message - from a buzz word to a recipe for building arches. Nowadays, internet memes are understood as a manifestation of networked creativity, "(post) modern folklore" (Shifman, 2014); an ironic, humorous statement, which has become wide-spread online (Davison, 2009, p. 122); a variety of metaphorical utterance (Piata, 2016); or artifacts of participatory digital culture (Wiggins \& Bowers, 2014). 
A considerable body of writings regard the Internet meme as a means of shaping the news agenda, a mechanism allowing to search for like-minded people and construct a collective identity, and a tool of political communication (Gambarato, Komesu, \& Tenani, 2018; Milner, 2013; Ross \& Rivers, 2017; Shomova, 2019). Such a diversity of approaches and definitions, among other things, results from the high variability of memetic content, whose extant scholarly classifications are based on different parameters and typological foundations (see Shomova, 2018, pp. 58-84). Using only the semiotic and genre criteria memes can be divided into numerous subtypes: verbal (e.g., hashtags, speech clichés, abbreviations, etc.), audial (e.g., melodies and sound imitations), visual (e.g., GIF files, photoshopped images, collages), and mixed (e.g., demotivators, which is a special format of the visual meme in a black frame, or coubs, which are short repeating videos, the Russian analogue to Vine videos).

However, it is more pertinent for the present study that some researchers interpret this phenomenon as a "new-literacies" practice, without which contemporary social skills of reading and writing - driven by the digitalization of our surroundings - would not be possible (see, for instance, Lankshear \& Knobel, 2006). Prochazka (2014, p. 70) claims that " $[\mathrm{t}]$ he ability to produce, decipher, understand and enjoy most of the internet memes requires new skills, strategies, dispositions, and social practices." Knobel and Lankshear $(2005$, p. 16) remark that "the literacy practices of meming also involve people deciding on how they will choose to read or interpret a meme and the 'spin' they will give it as they pass it along," while Scolary (2018) considers memes within the context of transmedia literacy.

A key aspect of adequate perception of memes is a critical stance with regard to the meaning memes convey: the ability to decipher, interpret, and evaluate their meaning. However, so far, memes have hardly been regarded as verifiable: they have been perceived as one of the few types of messages that are not assessed in terms of veracity and objectivity of the information they transmit. According to Budovskaya (2013, pp. 71-72), 'a meme cannot and need not be 'accurate,' 'correct' or 'virtuous', in order to thrive it needs but be attractive and memorable."

Meanwhile, memes have ceased to be merely a pastime or entertainment; for younger internet users they are increasingly becoming a way to respond to the news agenda, a channel for making a personal statement on significant news topics. A brief survey of the contents of popular public profiles containing memes on Russian social media, such as Lentach or Nastoyaschiy Lentach in VKontakte, the leading Russian social network used by approximately $42 \%$ of the population (Volkov \& Goncharov, 2019), would be enough to prove that a significant portion of memes is dedicated to media representation of current economic, political, cultural, and sports-related news. As sociological surveys demonstrate, for the Russian youth, "the main information source nowadays is not television, but social networks;" moreover, $85 \%$ of young people use social media "daily or nearly daily" (Volkov \& Goncharov, 2019). Over 70\% of young Russian audiences learn about current 
events in Russia and abroad, including political news, through the internet (Volkov \& Goncharov, 2017).

Furthermore, the practice of media consumption registered by various surveys already indicates that younger Russians' notions of the news agenda tend to be shaped by the domestic memosphere. It was for a good reason that the St. Petersburg online-newspaper, Bumaga, having interviewed 18-year-old city dwellers on the eve of 2018 Russian presidential elections, mentioned in the headlines that the youth learned about presidential candidates from memes (Merzlikin, 2018). Here are a couple of quotes from this publication: "Nowadays everything undergoes memetization... As for me, this is a positive tendency: politics becomes exciting for the youth" (Nikita, a student of St Petersburg State University). "I'm used to some of them <presidential candidates $>$, while others I hadn't even heard of before the campaigns started. Except perhaps Grudinin, but that's because of the memes, of course" (Eduard, a student of Leningrad State University).

This situation is far from unique, and Russian students are not an exception in recognizing memetic content as an important news source. Head et al. (2018) note:

Throughout our pre-study focus groups, students in each discussion brought up political memes as "news" that they engaged with and followed... For many, political memes provided a much-needed dose of humor in the midst of news about the world's serious problems and tumultuous times... As one student, a health sciences major, explained, "Political memes, while crudish, begin important conversations". Others considered memes a natural springboard for "researching fact vs. fiction or opinion vs. reality." (pp. 11, 13)

Why can these observations be considered an alarming factor of contemporary media environment's development? Memes, which constitute a significant portion of social-media content and a primary vector of users' communicative exchange, have already turned from an entertainment to an information source, without acquiring, in their young audiences' opinion, the features of messages in need of verification. "Rather than factually reproducing news items, Internet memes penetrate official discourses by carnivalizing them" (Heiskanen, 2017, p. 21). The ambivalence of the memetic content means that nowadays, arguably, "meme literacy" has to be viewed as a significant facet of contemporary media and information literacy as a whole and can be seen as part of news literacy.

\section{MEDIA LITERACY IN RUSSIA}

Media education and interpretation of media literacy issues have a long tradition in Russia (on the evolution of Russian approaches to media education, see Feodorov, 2009). However, so far, Russian researchers have more frequently and willingly considered media and information literacy (MIL) issues from the standpoint of instrumental use of the media, such as the cinema or the press, rather than within the framework of supporting citizens' critical thinking. Many Russian researchers and educators still do not see it worth distinguishing between media education and use 
of media devices in the learning process. Nowadays, the educational aspect of MIL still seems the most relevant to Russian theorists and practitioners.

Here, again, the Russian situation is not at variance with the global context: contradictory approaches to understanding MIL have been pointed out by many researchers. According to Leaning (2019, p. 7), MIL has historically been used to describe a range of educational practices. Leaning (2019) refers to Potter (2010) who recognizes that over 20 different definitions are in use and that there is little consensus or fixed meaning. Indeed, organizations, such as the National Leadership Conference on Media Literacy (Aufderheide, 1993), the United Kingdom's (UK's) Office of Communication (OFCOM, 2004), and the United States (US) based National Association for Media Literacy Education (National Association for Media Literacy Education, 2015) offer different skill-related definitions. As an alternative to the skills-based methods, scholars have presented approaches that are based on developing criticality in students (e.g. Silverblatt \& Eliceiri, 1997) and viewing media literacy as a social and cultural practice (Sholle \& Denski, 1994). (Leaning, 2019, p. 7)

The courses on media literacy and news literacy, offered by the National Research University Higher School of Economics (Moscow) since 2013, are based on the understanding of media literacy as citizens' critical thinking, a key competence for a person of the digital era and an important element of media ecology. Relying partly on the work done by the Center for News Literacy at the Stony Brook University (USA), MIL at the Higher School of Economics includes both a compulsory subject for Bachelor's Degree in Journalism and elective courses (part of a "minor," subsidiary two-year educational program) for students of other specializations, such as law, economics, psychology, design, computer programming, literature studies, sociology, and so on. While in these courses, students are taught to verify information sources, to distinguish news items from advertisement and entertaining materials, to "see" propaganda technologies in documentaries and feature films, to identify manipulations in photography, and, above all, to decode materials of different mass media - decoding of memes still has not been included in MIL curriculum. Such tasks (extremely localized) are only beginning to appear in various practical guides and training courses in MIL of different countries. Thus, one section of a textbook developed by media literacy instructors from Kazakhstan (Asanbajeva, 2019b), features a short task involving critical analysis of a meme. The students are asked to identify hidden meanings that can be found in this content. (Asanbajeva, 2019a)

\section{KEY PROBLEMS OF NEWS REPRESENTATION IN MEMES}

Based on what has been said above, the key problems of the news representation in memetic content can be identified as follows. First, the distortion of facts (to the point of disinformation), which necessitates a critical engagement with memes, including - surprising as it might sound with regard to this type of content - their fact-checking. Young social media users are not accustomed to this procedure, but 
the issue of up-to-date information being significantly distorted in memes has already been touched upon in the media. Thus, after the retirement age in Russia was raised, which led to mass protest actions all over the country, a meme with President Putin's portrait and the following text gained popularity throughout Runet (the Russian Internet): You must know this! Putin doesn't write laws, he only signs them! According to the Constitution's Article 107 Paragraph 3, he has no right not to sign! Should he break the law, the Federation Council, following Article 93, will send Putin to impeachment! Pass this on, don't let the enemy shape the opinion that Putin is to blame!

An online newspaper, Meduza, fact-checked this meme thoroughly, juxtaposing each of its statements with Russian legislation to show the unfoundedness of this text, which was aimed to "distance" Vladimir Putin from the unpopular measure (Dmitrijev, 2018). This certainly did not stop the meme's viral spreading, but it did serve as another reminder of the necessity to verify the information coming from memetic content;

Second, incomplete, fragmentary coverage of an event or a person (including those from the political sphere). Even before the survey was conducted, one of the students at a MIL seminar said: "I have no clue who Elon Musk is, but I know that something is constantly wrong with him, I've seen memes about him and his Cybertruck." Online jokes had not motivated this student to find out something about this person, however, they led her to conclude that "something is constantly wrong with him." Third, the above-mentioned "carnivalization" of news discourse is not always obvious for a young audience. Even when they realize that most memes are a variety of humorous, ironic viral content, Internet users sometimes tend to take the information transmitted in this way seriously (as will be shown below, the corroboration of this observation formed one of the results of the present research).

\section{METHODOLOGY}

Reflecting the urgent necessity to better understand and develop "Meme Literacy," a survey concerning the interpretation of Runet memes was conducted in Autumn 2019 among the bachelor students of the National Research University Higher School of Economics, whose curricula included media literacy. The students could respond anonymously. The questionnaires were distributed in paper form, not electronically. Besides the questionnaire itself, the study was based on the method of participant observation of the processes of memes' generation and spreading in Russian social networks (primarily VKontakte).

The survey was expected to answer the two major research questions: (1) Can we suppose that the student audience perceives memes in social media as a news source? (2) Whether the student audience tends to verify the visual and verbal content on which the meme is based? The working hypothesis of the research assumes 
that a lack of critical thinking, with regard to memes, leads to the information being distorted and its meanings reduced. The students were asked to analyze five memes from the following social networks: VKontakte (public profiles from Lentach and Nastoyaschiy Lentach), Telegram messenger (/po channel), and personal accounts on Facebook. The memes were selected due to their popularity in Runet, from 2017 to 2019. Two out of five memes chosen for this questionnaire dealt with news topics of international significance (i.e., the G20 Summit of 2017 and the Greta Thunberg's speech at the UN Climate Action Summit in 2019), the other three reflected domestic news (i.e., 2018 Russian presidential elections, 2018 pension reform, and 2019 protests in Moscow). In terms of genre and semiotics, the memes differed; therefore, the students were asked to decode both visual (with and without caption) and verbal memes, including a set expression and a hashtag.

The questionnaire was offered as part of the MIL course - when the lectures were over, but the practical classes were still being taught - in two groups of the second-year students: those majoring in Journalism (86 questionnaires were submitted, but one of them was empty, so 85 people have answered the questions) and minor subject students, representing various specializations $(N=53)$. In total, there were 138 respondents. Such a selection of students of media and other specializations has allowed making some additional observations as to the ways young audiences interact with Internet memes, the degree of the respondents' familiarity with the news agenda and their ability to decode the meaning of memetic content. The vast majority of people in the survey $(N=129)$, in response to the first question, gave their age as 19 or 18 years old; two as 17; four as 20; two as 21 ; and one as 24 .

The second question consisted of a request to give a brief definition of an Internet meme, in the respondent's own words. For the subsequent decoding of memetic content, it was necessary to identify to what extent the students understood the phenomenon they were faced with and reflected on the specifics of this type of messages. Furthermore, the students were presented five memes, and they were asked to identify the news topic on which the meme was based and to suggest their own interpretation of the picture's or the verbal expression's meaning.

\section{FINDINGS}

Some important observations were made already while examining the students' answers to the question of what an internet meme was in their opinion. The vast majority of the respondents noted a meme as belonging to the culture of laughter. For example, they described memes as "an ironic image," "an internet joke," "a colorful catchphrase," "a gag," "a funny template picture," "a contemporary interpretation of an anecdote," "a mini caricature," and so on, emphasizing the satirical, humorous, or entertaining nature of such content. References to internet memes' virality (e.g., "a viral joke," "a viral video," or "something that lends itself to multiple spreading and sharing") or to the emotional element of these messages (e.g., "vividly expresses a certain emotion," or "has an 
established context or emotion") were less frequent. On the whole, it can be concluded that the essential features of an Internet meme, as a communicative phenomenon, were intuitively clear for the students. What is more, among the students minoring in media and majoring in non-media subjects (such as law, psychology, sociology, economics, or design), there was one person whose definition of a meme had reached a certain level of generalization: for him or her, a meme referred to "a piece of information which has achieved viral spreading due to the emotions triggered by this information (funny; we can't discuss it openly, so we make jokes)."

It is noteworthy that, compared to the definitions given by the students of the minor subject (i.e., students not specialized in media), the students of the BA program in Journalism offered more academic answers to the question. The future journalists define memes as "a cultural unit" or "information unit" that have distinctive features; thus, a meme has "a particular association attached to it," it can serve as "a unit of the internet's cultural code," it is a unit of content that "has become popular and is used in [a] humorous context." There is also a definition of a meme as "a unit of information, which reflects a person's position." What is even more important within the framework of this research, the students of both groups report that memes in their milieu are regarded as something highly relevant, significant in terms of the transmitted information, directly connected to the news agenda, to high-profile current events. Judging from the questionnaire's definitions, for this student audience, memes are connected to "up-to-date topics (news agenda)" or "some urgent news topic." They "sometimes contain news important for the reader" or "refer to some current event which has generated public response." Being "a way to transmit information ironically" including "a fact, a news topic, which has achieved wide spreading," memes, according to the respondents, "are based on current events." In the authors' opinion, this confirms the tendency among young people to perceive Internet memes as a news source; consequently, this type of media content requires careful consideration from specialists in the field of news literacy and media literacy in general.

\section{The G20 leaders' summit meme}

The following part of the questionnaire, as indicated above, consisted of tasks involving interpretation of memetic content. Firstly, the students were presented with a fake photo of the G20 Summit in 2017. The meme picture (see Figure 1) showed president Vladimir Putin surrounded by the leaders of different countries, who listened to him attentively. At some point, this meme went highly viral throughout Runet and served as a basis for users' creativity (for examples on constructing this meme, Meduza, 2017). In the original summit picture (see Ozer, 2017), the central seat was empty. The photoshopped image not only misled many Russians, including some celebrities who shared it on their social media pages, but also turned into a popular meme, where Putin's place in the center was subsequently occupied by 
popular Internet characters (e.g., Stoned Fox or Grumpy Cat) or, alternatively, by long deceased politicians (such as Winston Churchill).

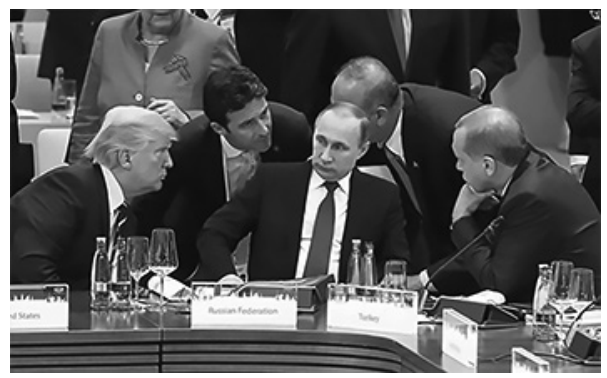

Figure 1. The meme picture of the G20 Leaders' Summit in Hamburg

Note: For the original picture, see Ozer (2017).

Since the popularity of meme peaked in 2017, and because the "life cycle" of it was already over, this task aimed at finding out to what extent the student audience was ready to trust the "visible iceberg" (i.e., the seemingly documentary photo) and whether there will be any respondents attentive enough to identify the image as fake or at least to try to verify the information coded by the meme.

Only six students from the minors' group (i.e., non-media students) detected the fake or suspected the use of Photoshop on the image (e.g., "I think... Putin's figure has been inserted artificially" or "This photo is a fake, it was in fact another politician's seat and it was empty"). In addition, seven more students identified the meme as ironic or sarcastic (for example, "This meme is used in the context of ironical perception of Russia as a key figure in global politics and economy" or "The leaders of other countries seek Putin's advice... Sarcasm") - in total, that is $24.5 \%$ of the group. Among the students of BA in Journalism the percentage of those who approached the picture critically was even lower, at about $15 \%$. Specifically, seven students identified the picture's "artificiality," with answers ranging from, "As far as I remember, Putin is absent in the original picture," to "The photo itself was fake, Putin was added with the help of Photoshop. But everyone started posting it." As one person admitted: "My course mates explained [to me] that it was Photoshop." Furthermore, six more students pointed to the ironic nature of this visual statement (e.g., "Perhaps it's irony with regard to Putin's influence and power" or "It can be interpreted as heightened attention to Russia. Irony"). One person, without doubting the photo's documentary quality, noted that it "can serve as a tool for state propaganda, because the heads of other countries seem to attend to V.V. as if he were the leader of G20."

It must be emphasized that the questionnaire was given to the students directly after a lecture dedicated to the power of visual image and contemporary manipulations on internet pictures. However, neither the lecture and all the material it 
presented nor the mere attention to the fake picture's details (for instance, the ribbon of St. George on Angela Merkel's dress, which has been used in Russia over the last few decades as a symbol of the victory over Nazi Germany) motivated the majority of respondents to approach the meme critically. Even though most students, judging from their definitions of memes, realized that such content is "a joke," "a gag," "a caricature," or "an anecdote," they took the information transmitted by this meme seriously, suggesting the following interpretations:

- "Apparently, the point of this meme is that Putin is the most famous and influential person not only in Russia but in the whole world."

- "Putin's opinion is important for everyone. Putin's authority on the international arena is undeniable."

- "The meaning of this picture: the actions and words of G20 countries' leaders depend on VVP's politics."

- "Politics' big boss, on whose opinion the whole world relies."

- "This meme can lead to the conclusion that Putin, just like Russia, is surrounded by pressure on all sides... Representatives of other countries, just like their countries as a whole are hostile to Russia."

- "Putin looks like 'a politician, a leader and a fighter'. Donald Trump, the president of the most powerful country in the world, attends to him."

"The meaning: other countries' pressure on Russia... I think this photo has not been staged."

Some answers to this question attempted to concretize and "build up" the meaning of this meme with the help of political details (e.g., "Leaders of other countries have gathered around V.V. Putin at an international conference in order to discuss the question of Ukraine. Putin's opinion is influential...") or to view this image as archetypical (e.g., "The picture refers to a divine motif - the Last Supper, where Putin has replaced Jesus"). Therefore, we can reach a conclusion that the vast majority of respondents, even when warned that they are dealing with a meme and realizing the humorous nature of memes, still regard photoshopped viral photographs as a source of actual news information that they are not inclined to double-check.

\section{The Greta Thunberg meme}

As the next task, the students were asked to interpret a collage of four images, featuring a famous photo of the climate activist Greta Thunberg juxtaposed with pictures of a dragon, a mermaid, and a unicorn (see Figure 2). The caption reads: "Fantastic creatures." Young Swedish activist, Greta Thunberg, and her speech at the United Nations (UN) Summit caused an ambivalent, skeptical, and sometimes even aggressive reaction in many Russian mass media. The point of the task was to track the meanings the students would be ready to ascribe to this meme and to try to determine what factual information about the event or person they possess. 


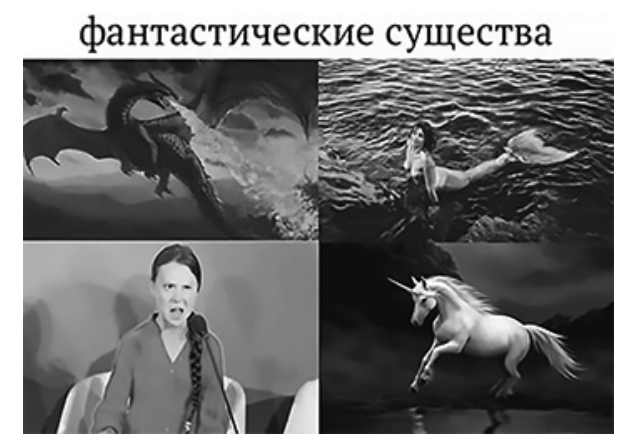

Figure 2. The "Fantastic creatures" (fantasticheskie sushchestva) meme

Source: Telegram, /po, 11.10.2019 blob:https://web.telegram.org/681b6d65-72ef-4d0dbb72-4ae92f8175bc

Among the minor subject students, $17 \%(N=9)$ of the respondents failed to recognize Greta and identify the meaning of the meme (e.g., "I don't get who this is," "I don't know," etc.). Among the future journalists, only $9.4 \%(N=8)$ failed to recognize Greta and identify the meaning of the meme. This shows that the students of media-related programs engage more actively with the news agenda and watch television news more often. However, even when they recognized the heroine of the collage, though sometimes misspelling her name, the students - especially those from the minor subject students' group - often indicated that they could not see the point of this meme. In contrast, some comments were quite elaborate, offering an adequate, unemotional and sufficiently accurate description of the event (i.e., environment-related speech at the UN) and Greta Thunberg's views. Examples of such comments follow:

- "Greta Thunberg is a girl who was able to do the impossible, something completely incredible. Such eco-activism is quite rare...That's why here she is presented as one of non-existing 'fantastic creatures."

- "She has been called a fantastic creature, because for people her speech became a phenomenon, an exception to the rules."

- "In my opinion, this meme reflects the position of those adults who before the Greta events had considered the younger generation as 'lost', incapable of anything important on a global scale."

However, many more answers (in both groups) contain rather dogmatical, harsh judgements with regard to the meme's heroine. It appears that these opinions are not based on knowledge of the source (Greta's speech) but, instead, reproduce the position voiced by many Russian mass media:

- "She is shown here as one of fantastic creatures, most likely, because her destiny, views, and actions are unclear. I think her UN speech was absurd."

- "She stands among other fantastic creatures. This means that this girl's story isn't true, it's a fake." 
- "She is known for her pseudo-scientific views... She is no more than another social talker."

- "The point is that she is a fantastic idiot. She grew famous because of the drama she played at the UN."

Furthermore, many of these answers "mirror" a view popular with Russian mass media that Greta's opinions are some kind of a "commercial project," for examples:

- "Perhaps, the point of this meme is that Greta is a governmental put-up job and she doesn't exist in reality, same as mermaids, unicorns etc."

- "It is a funded project, and her parents make money on her."

- "She's as fake as dragons, etc. That is, her whole image is false."

Moreover, it is worth paying attention to the generalizing constructions used in such comments, such as:

- "The point is that everybody thinks she lives in a dream world."

- "The majority of users share a negative view of Greta, believing her to be crazy and her actions useless."

- "Only idiots believe Greta's opinions to be honest and these creatures to exist."

Forgetting, once again, about the humorous and entertaining nature of memes they identified earlier, the respondents perceive this collage as a source of additional information on a current news topic or as an opinion that confirms the statements voiced by mass media (the survey was conducted exactly as the debate about Greta Thunberg's recent UN speech was in full swing), rather than as merely funny content, not worthy of serious consideration. Moreover, taking everything the meme says seriously, at face value, the students do not plan to verify this information in any way.

\section{The Grudinin meme}

The following task in the questionnaire reminded the students of a very popular viral phrase dating back to the recent Russian presidential elections and referring to one of the candidates. In January 2018, social media of Runet (VKontakte, Twitter) were flooded by identical posts, such as: "I've never voted in elections, but now I'm surely going to vote for Grudinin! People's candidate." According to numerous sources, they were spread by bots at the initiative of the election team of the Communist Party candidate. The slogan, as a whole, and its fragment "people's candidate" gave rise to many internet jokes and turned into verbal memes. This attempt to create a "pre-planned" protective meme was rather clumsy, but the goal was reached: many social media users who had never before heard of Pavel Grudinin got a primary information injection with regard to this politician, and is level of recognizability was raised. The question aimed to identify the associations young audiences had in connection with the name of the recent presidential candidate and to determine to what extent the recipients were ready to feel the irony of this meme.

Among the students of the minor subject, 15 people (28\%) stated that they did not know the context or reason for the meme's appearance (even though some of 
them indicated that the phrase "sounds familiar"). Among the students of journalism, similar responses were given by 16 people (about 19\%). More often than the students of the minor subject, they answered with either "I don't know who Grudinin is" or "No clue whatever." In the authors' opinions, this has to do not only with the fact that the presidential elections took place a year and a half before the survey but also with the lack of interest in politics in general and elections in particular among Russian youth. As Volkov (2018) suggests, "The youngest follow news, discuss political topics with colleagues and friends twice less frequently than the oldest age group; vote in elections of different levels three times less frequently."

Among those ready to answer the question, there were students who were fully aware of the irony of naming Grudinin a "people's candidate" (e.g., "It was spam written by bots. This meme satirizes the absurdity of using bots in order to promote a politician in social media. Grudinin was a candidate representing the Communist Party of the Russian Federation;" "The meme ... was related to Grudinin's election campaign, it's a PR device;" "This expression appeared because of fake comments posted in the network of Grudinin's 'cheerleading squad"'), as well as those who took the expression "people's candidate" for the actual election slogan of Grudinin and the sarcastic meme - for the genuine position of some internet users' (e.g., "In our country there are many people who don't vote, but the arrival of Grudinin with his campaign - that he is people's candidate - changed the situation;" "Grudinin in his election campaign made the words 'people's candidate' his slogan;" "People have this notion that candidates from common strata are more honest ... he is 'the guy next door', one of the people;" etc.). However, the most noteworthy result of the survey - in connection with this set expression - seems to be the confirmation of our hypothesis: for young Russians, memes serve as a source of relevant information on various topics, including voting. Many of those who failed to name the party represented by Grudinin at the elections, misspelled his name, mixed up the slogans and ideas of his election campaign, were still able to accurately indicate his occupation (e.g., "he plants strawberries" or "he is known as the major strawberry supplier"), and features of appearance (e.g., "Grudinin is known for his moustache," "this candidate also had a moustache," etc.). In fact, as the head of a property specialized in growing strawberries this politician earned the nickname of "strawberry king" and having promised in an interview to shave his moustache if he doesn't get a specific number of votes in the elections, Grudinin became the character of numerous memes on the topic.

Thus, Grudinin being firmly associated with jokes concerning strawberries and moustache-shaving, about one half of the respondents, regardless of how they interpreted the "people's candidate" meme, felt compelled to add to their answers some comments covering these two semantic accents. Sometimes this was the only answer to the question (e.g., "Socialist candidate. Grows strawberries;" "Politician. Shaved his moustache;" "likes strawberries, has a brush-like moustache;" "known for memes and strawberries;" "known for strawberries, bars of gold, and 
the promise to shave his moustache," "I know that Grudinin shaved his moustache on a bet;" "also he shaved his moustache, and this turned into another meme;" "I've heard only of memes about his moustache;" etc.). In the authors' opinions, this clearly testifies to the reduction of the semantic field connected to this political figure: as the survey revealed, the majority of respondents got the information about Grudinin from the memosphere, and this information was highly imprecise.

\section{The \#Dopyskay meme}

The following task of the questionnaire involved the hashtag, \#dopuskay ["let them in"], which became a symbol of summer 2019 protests in Moscow as a response to independent candidates not being allowed to take part in the elections to the Moscow City Duma. The respondents were asked to say whether they were familiar with this meme, if they had used it themselves, and what it symbolized. The aim of the task was to determine to what extent the students were familiar with the current news agenda and - in the case of using hashtags — how well they understood their actual informational meaning.

Twenty-four students (45\%) of the minor subject group had not heard of this hashtag and did not understand the meaning of the expression that had become a meme (i.e., they could not even make guesses: there were answers like, "No idea" or "Never heard about it. Often, a negative answer to this question was found in the questionnaires of the same respondents who had not heard the Grudinin meme or could not recognize Greta Thunberg. Among the students of journalism, such answers were given by 41 people ( $48 \%$ of the group). Among the rest of the respondents, many gave answers like: "I haven't heard it, but I think..., "I don't know, but I could suppose...," or making correct guesses regarding the meaning of this hashtag and its connection to 2019 summer protests in Moscow.

Only a few students of the minor subject group gave an accurate answer as to the nature of this hashtag; however, at the same time, their attitude to the protests ranged from positive to negative or neutral (e.g., "[it] is connected to independent candidates not being allowed to take part in the elections to the Moscow City Duma. I have used it on Twitter. It symbolizes disagreement with the Central Election Commission's position;" "It is a symbol of mass protest against the authorities. I haven't used it and on the whole my attitude to it is negative;" or "This is a hashtag in support of independent candidates' admission to the Moscow City Duma elections... It symbolizes the consolidation of the civil society in the struggle for its rights"). A similar picture is visible in the future journalists' questionnaires. It is noteworthy that they are as little aware of the reasons and details of the mass protests that took place in Moscow as the students of non-media specializations. In a sense, this disproves an assessment of the protest movement as "growing younger" and consisting mainly of students - an opinion that is widely spread in Russia nowadays. What is more, a number of answers shows respondents "thinking up" the 
meaning of the meme, \#dopuskay, which has been interpreted in the following ways: "Perhaps, it is connected to domestic violence?" or "Most likely it is something like an abbreviation of the phrase "What seems impossible is actually possible". On the whole, a political hashtag as a variety of memetic content has proved to be the genre most far removed from the survey's participants and caused the greatest interpretation difficulties when the news topic connected to it was unfamiliar to the students.

\section{The Pushkin meme}

Finally, the fifth and last meme presented to the students (see Figure 3) consisted of an ironic picture based on a famous painting by the artist Alexander Naumov showing the fatal duel of the famous Russian poet, Alexander Pushkin. The caption read: "Alexander Sergeevich Pushkin died at 37. And what have you done for your country?", signed by "The Pension Fund of the Russian Federation." After the 2018 reform, which introduced a dramatic increase of the retirement age for both sexes, social networks of Runet were flooded by similar memes. The point of numerous jokes was that the shorter a Russian's life, the more profitable it is for the country, because the state will not have to pay them old age pension.

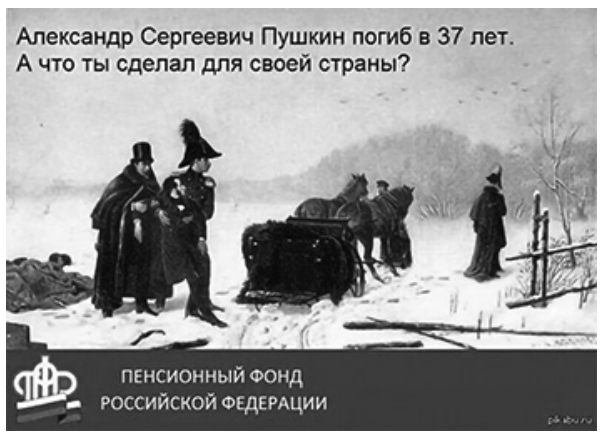

Figure 3. Meme on Alexander Pushkin

Note: This meme was widely distributed in the personal accounts of Twitter, Facebook, and public profiles of the Vkontakte network during the summer of 2018. Even before the pension reform, it was distributed on various resources of the Runet, for example, Pikabu https://pikabu.ru/story/a_chto_tyi_sdelal_dlya_svoey_stranyi_18927 31?fbclid=IwAR0zDTy_C158jAOhBsCkft1s8u6_fliTsr4WDyIcdCR2YcBZbE2O_6fiUpA.

The pension reform, which directly influenced the life of nearly every family in Russia - unlike, for instance, the 2019 protests in Moscow or Greta Thunberg's speech - was expected to be a highly recognizable news topic, even for a young audience, though this event's topic is not a priority among younger Russians' interests. As a matter of fact, the informational accent that served as a basis for the creation of this "pikcha" [picture], as we had supposed, proved to be easily recognizable for the survey participants. Only $1(1.9 \%)$ of the students from the minor subject group failed to recognize the topic of pension reform and noted that the 
meme is unclear to him or her; among the future journalists, however, there were 4 such persons (4.7\%). The vast majority of the students have interpreted the ironic meaning of the picture quite accurately: "The meaning: The state needs people to die before they reach retirement age, so that there is no necessity to pay them old age pension;" "The point of the meme is that you should die earlier so that the Pension Fund of Russia retains more of your money and they don't have to pay you pension;" "The earlier you die, the better for the state - they won't have to pay you pension;" or "The meme satirizes the state's cynical attitude to the society ..."

However, as this research has shown, this meme, like all the above-mentioned, still was not adequately interpreted by all the respondents. Moreover, it became this questionnaire's leader in terms of collecting directly opposing and even completely wrong interpretations. A number of respondents have identified not the pension reform but the historical fact - Alexander Pushkin's duel and death - as the central theme and the occasion for this meme's creation: "It must be about the poet's huge contribution to literature. An analogy is drawn with nowadays situation, when few become a success at such an age;" or "The point of the meme is that Pushkin died young, but during his short life he had made an enormous contribution to Russian literature. But it's not quite clear what does the Pension Fund have to do with it?" Some of those who have correctly identified the news topic, have tried to add to the meme's meaning by finding "economic" or "ideological" justifications for the new legislation: "Because he died young, before reaching retirement age, the demographic pyramid moved upwards. The proportion of elderly population became higher. The authorities decided that it's possible to shift the retirement age;" or "This meme says that the pension reform is absurd and impractical ... people will work like crazy ... and all for the sake of an abstract notion - patriotism." Finally, there have been students who saw the picture as an attempt to promote the Russian Pension Fund, rather than mockery of this organization: "I don't know the news topic, but perhaps it urges to use the Pension Fund (a kind of advertisement)" or "Propaganda of the pension reform."

Thus, in our opinion, a conclusion can be made that the decoding of the five presented memes - which the students of the Higher School of Economics undertook upon the authors' requests - exhibits the whole gamut of the above-stated representation issues in the memosphere related to news agenda. Being essentially a "carnivalization" of the news discourse but perceived as a direct news source by younger audiences, memes reduce and distort meanings. Sometimes memes are even capable of misinforming internet users, becoming too complicated to understand (the hashtag case) or acquiring an openly propagandist nature (as in the case of the fake photo of the G20 summit).

\section{CONCLUSIONS AND DISCUSSION}

Considering memes as a specific form of persuasion and propaganda, as a way of expressing "opinion from below", or as a means of public discussion, Shifman (2014, 
pp. 119-123) argues that these communicative units are capable of building a new worldview for contemporary human beings. Shifman (2014) writes: "We live in an era driven by a hypermemetic logic, in which almost every major public event sprouts a stream of memes" (p. 4). However, the opinion that memes are one of the means of conveying news information can potentially prove quite dangerous. One cannot always expect memes to present facts accurately. Moreover, the demand of accuracy, so far, is not even made with regard to memes as a specific type of content. However, being not only consumers but also producers of memetic content, younger users of Runet shape their own agenda by means of posts on social networks, adding their own informational emphases, highlighting - sometimes excessively - some names and events, and ignoring others. Considering that such content often goes viral due to its witty message or bright "packaging," we must remember that it is frequently approached uncritically by future recipients, who realize the entertaining nature of memes but still take the information they contain at face value.

The data gathered as a result of the survey conducted among 138 sophomores at the Higher School of Economics in Moscow decidedly cannot be regarded as definitive. However, it gives a certain cross-section of the perception of memes among Russian youth and allows making some conclusions as to how users decode meanings contained in memetic content. Acknowledging light-hearted, humorous, entertaining nature of such content, students still define memes as units of topical information, point to their connection with current news topics, and believe that they contain "facts." Even having taken a course in MIL, on which, in particular, the possibilities to manipulate visual images had been discussed, the vast majority of the respondents were easily taken in by fakes if those look like documentary photos. Similarly, the respondents were mostly satisfied by limited, imprecise information about events and persons yielded by memes, without seeking to verify it or to obtain additional knowledge. Occasionally the audience could interpret the memetic content in an incorrect way, imposing their own interpretation onto it. Therefore, this is currently a key manifestation of the lack of critical thinking with regard to internet content, which poses undeniable threats in terms of shaping an adequate news agenda in younger audiences' minds. The working hypothesis of this study, has been corroborated; though, obviously, perception of memes by Russian student audiences needs a further, deeper investigation.

It is noteworthy that the issues of memes' critical reception are nowadays attracting increasing attention of researchers from different countries. Thus, Elmore and Coleman (2019), who asked Middle School students to analyze political memes, note that:

\footnotetext{
through the strategic combination of imagery and captions, a political meme presents information as fact about a topic, an individual, or a specific group ... To critically read a political meme, students must be equipped with critical media literacy skills ... Critical media literacy is imperative given the prevalent and viral nature of media and its effects on people and public policy... As students begin analyzing the productive qualities of political memes, they start perceiving the memes as argumentative, visual texts rather than just funny or provocative pictures on their Twitter feeds. (pp. 1, 3)
} 
Realizing that memes have currently turned into a specific environment in which news inhabit - an environment often out of reach of the official news agenda - we must not believe that they reflect the whole variety of the existing viewpoints for the user, nor can we rely on their veracity. Developing the skills of critical thinking, we must now extend them to the Internet's memetic content, perhaps even establishing special classes in "meme literacy" and introducing them into the structure of contemporary MIL programs.

\section{REFERENCES}

Asanbajeva, G. (2019a). Modul' 1: Osnovnye ponjatia i printsipy MIG [Module 1: Translate the basic concepts and principles of MIL]. New Reporter. https://newreporter.org/2018/10/23/modul-1-osnovnye-ponyatiya-i-principy-medijnoj-i-informacionnoj-gramotnosti/2/.

Asanbajeva, G. (2019b). Uchebnoe posobie po mediagramotnosti. Elektronnaya versiya [The media literacy handbook. Electronic version]. New Reporter. https://newreporter.org/uchebnoe-posobiepo-mediagramotnosti/.

Aufderheide, P. (1993). Media literacy: A report of the national leadership conference on media literacy. ERIC.

Budovskaya, Y. V. (2013). Memeticheskiy podkhod k izucheniyu printsipovrasprostraneniya informatsii $\mathrm{v}$ sotsialnykh setyakh i sotsialnykh media [A memetic approach to studying the principles of information spreading in social networks and social media] (Doctoral dissertation). The People's Friendship University of Russia.

Davison, P. (2009). The language of internet memes. In M. Mandiberg (Ed.), The social media reader (pp. 120-134). New York University Press.

Dawkins, R. (1976). The selfish gene. Oxford University Press.

Dmitrijev, D. (2018, July 19). Putin chto, ne mozhetotklonit' zakon povyshenii pension nogovozrasta? [Can't Putin really veto the retirement age raise?] Meduza. https://meduza.io/feature/2018/07/19/ putin-chto-ne-mozhet-ne-podpisat-zakon-o-povyshenii-pensionnogo-vozrasta.

Elmore, P. G., \& Coleman, J. M. (2019). Middle school students' analysis of political memes to support critical media literacy. Journal of Adolescent \& Adult Literacy, 63(1), 29-40. https://doi.org/10.1002/ jaal.948.

Feodorov, A. V. (2009). Mediaobrazovanie: vchera i segodnya [Media education: Yesterday and today]. UNESCO MOO VPP “Informatsiya dlya vsekh” Publishers. https://www.ifap.ru/library/book430. pdf.

Gambarato, R., Komesu, F., \& Tenani, L. (2018). "I will not become an Internet meme": Visual-verbal textualization process in the study of the power and resistance in Brazil. Acta Scientiarum Language and Culture, 40(2), 1-11. https://doi.org/10.4025/actascilangcult.v40i2.43714.

Head, A. J., Wihbey, J., Metaxas, P. T., MacMillan, M., \& Cohen, D. (2018). How students engage with news: Five takeaways for educators, journalists, and librarians - the News Study Report. https://files. eric.ed.gov/fulltext/ED591128.pdf.

Heiskanen, B. (2017). Meme-ing electoral participation. European Journal of American Studies, 12(2), 1-26. https://doi.org/10.4000/ejas.12158.

Knobel, M., \& Lankshear, C. (2005, November 30). Memes and affinities: Cultural replication and literacy education. Paper presented to the annual NRC, Miami, FL. Retrieved from https://www.researchgate. net/publication/249902174_Memes_and_affinities_Cultural_replication_and_literacy_education.

Lankshear, S., \& Knobel, M. (2006). New literacies: Everyday practices and classroom learning (2nd ed.). Open University Press and McGraw-Hill Education. 
Leaning, M. (2019). An approach to digital literacy through the integration of media and information literacy. Media and Communication, 7(2), 4-13. http://dx.doi.org/10.17645/mac.v7i2.1931.

Meduza (2017, July 10). "Nastoyashcheye foto" s G20: neudachnyy fotoshop ["Real photo" with G20: Unsuccessful photoshopping]. Meduza. https://meduza.io/shapito/2017/07/10/nastoyaschee-fotos-g20-neudachnyy-fotoshop-poklonnikov-putina-prevratilsya-v-mem.

Merzlikin, P. (2018, March 16). "Ochen' pechalno, chto moi pervye vybory takie": 18-letnie peterburzhtsy - o tom, za kogo budut golosovat', kak otnosyatsya k Putinu i pochemu uznaut o kandidatakh izmemov ["It's sad that my first elections are like this": 18-year-old Petersburg residents on how they will vote, their attitude to Putin, and why they learn about the candidates from memes]. Bumaga. https://paperpaper.ru/photos/first-election/.

Milner, R. M. (2013). Pop polyvocality: Internet memes, public participation, and the Occupy Wall Street Movement. International Journal of Communication, 7(1), 2357-2390.

National Association for Media Literacy Education (2015). Media literacy defined. https://namle.net/ publications/media-literacy-definitions/.

OFCOM. (2004). Strategies and priorities for the promotion of media literacy: A statement. Office of Communications.

Ozer, K. (2017). President of Turkey Recep Tayyip Erdogan talks with US President Donald Trump, accompanied by Foreign Affairs Minister of Turkey Mevlut Cavusoglu, during a session within the G20 Leaders' Summit in Hamburg, Germany on July 07, 2017. [Photo.] Anadolu Agency/Getty Images. https://www.gettyimages.com/detail/news-photo/president-of-turkey-recep-tayyip-erdogan-talkswith-us-news-photo/810196846\#/president-of-turkey-recep-tayyip-erdogan-talks-with-us-president-picture-id810196846.

Piata, A. (2016). When metaphor becomes a joke: Metaphor journeys from political ads to internet memes. Journal of Pragmatics, 106, 39-56. https://doi.org/10.1016/j.pragma.2016.10.003.

Potter, W. J. (2010). The state of media literacy. Journal of Broadcasting \& Electronic Media, 54(4), 675696. https://doi.org/10.1080/08838151.2011.521462.

Prochazka, O. (2014). Internet memes - A new literacy? Ostrava Journal of English Philology, 6(1), 53-74.

Ross, A., \& Rivers, D. (2017). Digital cultures of political participation: Internet memes and the discursive delegitimization of the 2016 U.S. presidential candidates. Discourse, Context \& Media, 16(1), 1-11. https://doi.org/10.1016/j.dcm.2017.01.001.

Scolary, C. (Ed.). (2018). Teens, media and collaborative cultures. Exploiting teens' transmedia skills in the classroom. http://transmedialiteracy.upf.edu/sites/default/files/files/TL_Teens_en.pdf.

Shifman, L. (2014). Memes in digital culture. MIT Press.

Sholle, D., \& Denski, S. (1994). Media education and the (re)production of culture. Bergin \& Garvey.

Shomova, S. A. (2018). Memy kak oni est' [Memes as they are]. Aspekt Press Publ.

Shomova, S. A. (2019). Vybory prezidenta RF - 2018 v zerkale memov: novye realii politicheskoy kommunikativistiki [Russian presidential elections - 2018 as reflected in memes: New realities of political communication studies]. Polis - Political Studies, 3, 157-173. https://doi.org/10.17976/ jpps/2019.03.10.

Silverblatt, A., \& Eliceiri, E.M.E. (1997). Dictionary of media literacy. Greenwood Press.

Volkov, D., \& Goncharov, S. (2017). Rossiyskiy medialandshaft: Osnovnye tendentsii ispolzovania SMI - 2017 [Russian mediascape: major trends in the use of mass media - 2017]. Levada-Center. https:// www.levada.ru/2017/08/22/16440/.

Volkov, D., \& Goncharov, S. (2019). Rossiyskiy medialandshaft 2019: televidenie, pressa, internet isotsialnyeseti [Russian mediascape 2019: television, the press, the internet and social networks]. LevadaCenter. https://www.levada.ru/2019/08/01/rossijskij-media-landshaft-2019/.

Volkov, D. (2018) Chem rossiyskaya molodez hotlichaetsyaots voikhroditeley [What differs Russian youth from their parents]. Levada-Center. https://www.levada.ru/2018/12/10/chem-rossijskaya-molodezh-otlichaetsya-ot-svoih-roditelej/.

Wiggins, B. E., \& Bowers, B. G. (2014). Memes as genre: A structurational analysis of the memescape. New Media \& Society, 17(11), 1886-1906. https://doi.org/10.1177/1461444814535194. 